\title{
MUATAN NILAI-NILAI KARAKTER PADA SASTRA ANAK BERJENIS DONGENG MODERN
}

Hidayah

\author{
SDN Tasikmadu 1
}

\author{
Email : hidayahshaan@gmail.com
}

\begin{abstract}
Abstrak: Berkaitan dengan Penguatan Pendidikan Karakter melalui Budaya Sekolah yakni kegiatan literasi, maka penanaman nilai-nilai karakter dapat dilakukan melalui cerita dongeng. Peneliti lebih memfokuskan untuk memilih cerita dongeng modern karena cerita jenis ini ditulis pada era globalisasi atau era yang sudah modern sehingga lebih relevan dengan kehidupan anak sekarang.Tujuan dari penelitian ini adalah untuk mendeskripsikan nilai-nilai karakter yang termuat dalam dongeng modern. Pendekatan yang digunakan yaitu kualitatif. Pada penelitian ini, peneliti bertindak sebagai instrumen utama. Hal ini berarti, keikutsertaan peneliti dalam proses pengumpulan data hingga analisis data mutlak diperlukan. Selain itu, peneliti mengembangkan instrumen tambahan berupa instrumen analisis nilai-nilai karakter dalam cerita dongeng modern untuk menunjang proses penelitian. Teknik analisis data pada penelitian kualitatif ini, yaitu (1) mengumpulkan data, (2) mentranskripsikan data, (3) memahami data secara umum, (4) pengkodean data, dan (5) membangun deskripsi untuk laporan penelitian. Hasil dari penelitian yang diperoleh yaitu, 13 muatan nilai karakter terkandung dalam unsur intrinsik tema, 44 muatan nilai karakter terkandung dalam unsur intrinsik penokohan, 15 muatan nilai karakter terkandung dalam unsur intrinsik latar, 46 muatan nilai karakter terkandung dalam unsur intrinsik alur, 11 muatan nilai karakter terkandung dalam unsur intrinsik amanat, dan 23 muatan nilai karakter terkandung dalam unsur intrinsik sudut pandang.
\end{abstract}

Kata kunci: Nilai Karakter, Sastra Anak, Dongeng Modern

\section{CHARACTER VALUE OF CHARACTERS IN CHILDREN'S LITERATURE MODERN TYPES OF STORIES}

Abstract: In connection with the strengthening of character education through the Educational Cultural literacy activities, the cultivation of character values can be done through a fairy tale. Researcher focuses on selecting a modern fairy tale for these types of stories written in the era of globalization or the modern era has been making it more relevant to the lives of children today. The purpose of this study was to describe the character values contained in a modern fairy tale. The approach used is qualitative. In this study, researchers act as the main instrument. This 
means, the participation of researchers in the process of data collection to data analysis is absolutely necessary. In addition, the researchers developed an additional instrument in the form of analytical instruments character values in a modern fairy tale to support the research process. Data analysis techniques in qualitative research, namely (1) collecting data, (2) transcribing the data, (3) understand the data in general, (4) encoding the data, and (5) establish a description of the research report. Results from the study were obtained 13 charge character values contained in the intrinsic elements of theme, 44 load the character values contained in the intrinsic elements of the characterizations, 15 load the character values contained in the intrinsic elements of background, 46 load the character values contained in the intrinsic elements of plot, 11 cargo value characters contained in the intrinsic elements of the mandate, and the 23 charges contained in the character values intrinsic elements viewpoints.

Keywords: Character values, Children's Letter, Modern fairy tales.

\section{PENDAHULUAN}

Pendidikan merupakan suatu proses yang dilakukan individu dalam mengembangkan sikap, cara berpikir, dan keterampilannya. Undang-undang No.20 tahun 2003, menjelaskan bahwa pendidikan adalah usaha sadar dan terencana untuk mewujudkan proses belajar secara aktif dalam mengembangkan potensi siswa untuk memiliki kekuatan spiritual keagamaan, pengendalian diri, kepribadian, kecerdasan, akhlak mulia, serta keterampilan yang diperlukan dirinya, masyarakat, bangsa dan negara. Dari pengertian tersebut, tersirat bahwa pemerintah menekankan pembinaan karakter dalam pendidikan nasional. Kebijakan baru dari pemerintah berkaitan dengan pembentukan karakter yaitu melalui PPK (Penguatan Pendidikan Karakter). Penguatan pendidikan karakter dilaksanakan dengan menerapkan lima nilai-nilai utama meliputi nilai-nilai religius, nasionalis, mandiri, gotong royong, dan integritas (Permendikbud Nomor 20 Tahun 2018 Pasal 2).

Terdapat beberapa pendekatan berkaitan dengan implementasi PPK dalam membentuk watak dan karakter anak, salah satunya yaitu pendekatan berbasis budaya sekolah. Implementasi PPK berbasis budaya sekolah dapat dilakukan dengan memberi ruang yang luas kepada siswa untuk mengembangkan potensi melalui kegiatan literasi (Permendikbud Nomor 20 Tahun 2018). Hal ini juga telah dikonfirmasi oleh salah satu guru Sekolah Dasar yang mengatakan bahwa, "kegiatan literasi ini bertujuan untuk menambah wawasan siswa mengenai pengetahuanpengetahuan baru di luar pembelajaran. Karena anak SD masih kecil, jadi yang sering dipilih siswa ya buku-buku cerita anak. Kami sebagai guru hanya mengarahkan saja.“ (Wawancara, 29 Desember 2018). Sejalan dengan pemaparan tersebut, pemilihan buku bacaan tetap harus mempertimbangkan hal-hal yang berhubungan dengan tahap perkembangan jiwa anak (Zulela, 2013:51). Jadi, guru dalam hal ini dapat membantu siswa dalam pemilihan buku literasi yang sesuai dengan karakteristik sastra anak.

Salah satu bacaan literasi yang diminati oleh siswa ialah dongeng. Hal ini telah dikonfirmasi oleh salah satu guru sekolah dasar negeri. Berkaitan dengan Penguatan Pendidikan Karakter melalui Budaya Sekolah yakni kegiatan literasi, maka 
penanaman nilai-nilai karakter dapat dilakukan melalui cerita dongeng. Hal ini didukung oleh penjelasan Hendri (2013:18) bahwa dongeng dapat dijadikan alat untuk mencapai tujuan pendidikan karakter dan sarana untuk menyampaikan ajaran kebaikan yang efektif. Namun, dongeng dapat dimanfaatkan sebagai alat untuk penanaman karakter jika ceritanya memuat nilai-nilai pendidikan karakter. Ketika dongeng tidak memuat nilai-nilai karakter, maka dongeng tidak memiliki kontribusi terhadap Penguatan Pendidikan Karakter.

Dalam penelitian terdahulu oleh Farida Iswahyuningtyas (2012) dalam jurnal penelitian "Nilai-Nilai Pendidikan Karakter Pada Materi Ajar Bahasa Indonesia Kelas 2 Sd Terbitan Tiga Serangkai," menjelaskan bahwa dongeng dapat meningkatkan karakter religius, nilai karakter pribadi yang baik, nilai karakter kepedulian sosial, nilai karakter kejujuran, nilai karakter kerja keras, dan nilai karakter cinta lingkungan maka, tujuan peneliti dapat mengembangkan lagi menjadi lebih banyak karakter yang diperoleh.

Mengenai pentingnya pemilihan buku literasi atau buku bacaan untuk siswa SD yang sarat akan nilai-nilai dalam kehidupan, maka peneliti tertarik untuk melakukan penelitian mengenai nilai-nilai karakter yang termuat dalam sastra anak berjenis dongeng modern. Peneliti lebih memfokuskan untuk memilih cerita dongeng modern karena cerita jenis ini ditulis pada era globalisasi atau era yang sudah modern sehingga lebih relevan dengan kehidupan anak sekarang. Dongeng modern dikaji berdasarkan unsur intrinsiknya, meliputi tema, penokohan, latar, alur, amanat, dan sudut pandang. Unsur intrinsik inilah yang membentuk sebuah cerita dongeng menjadi kesatuan secara utuh.

Penelitian ini dilakukan untuk menjawab beberapa rumusan masalah sebagai berikut, (1) nilai-nilai karakter apa saja yang termuat pada tema cerita dongeng modern, (2) nilai-nilai karakter apa saja yang termuat pada penokohan cerita dongeng modern, (3) nilai-nilai karakter apa saja yang termuat pada latar cerita dongeng modern, (4) nilai-nilai karakter apa saja yang termuat pada alur cerita dongeng modern, (5) nilai-nilai karakter apa saja yang termuat pada amanat cerita dongeng modern, dan (6) nilai-nilai karakter apa saja yang termuat pada sudut pandang cerita dongeng modern.

\section{METODE}

Pendekatan yang digunakan dalam penelitian ini yaitu pendekatan kualitatif. Penelitian kualitatif, terjadi secara alami, apa adanya tanpa manipulasi dan menekankan pada deskripsi secara alami (Arikunto, 2006:12). Oleh karena itu, penelitian ini menggunakan jenis penelitian analisis isi. Pada penelitian ini, peneliti bertindak sebagai instrumen utama. Hal ini berarti, keikutsertaan peneliti dalam proses pengumpulan data hingga analisis data mutlak diperlukan. Selain itu, peneliti mengembangkan instrumen tambahan berupa instrumen analisis nilai-nilai karakter dalam cerita dongeng modern untuk menunjang proses penelitian.

Lokasi pelaksanaan penelitian ini dapat dilakukan dimana pun. Hal ini dikarenakan sumber data yang digunakan dalam penelitian berupa sumber non manusia dan tidak melibatkan instansi manapun. Sumber data pada penelitian ini 
yaitu lima cerita dongeng modern pada Buku Kumpulan Kisah "Binatang Kecil yang Cerdik Lucu dan Menggemaskan" yang ditulis oleh MB. Rahimsyah AR (2018). Cerita-cerita dalam buku ini dipilih sebagai sumber data karena sesuai dengan karakteristik dongeng modern.

Sehubungan dengan sumber data yang digunakan, maka data yang diambil dalam penelitian ini berupa kata-kata atau kalimat yang terdapat pada cerita dongeng modern. Data dikumpulkan menggunakan teknik studi dokumenter. Untuk memudahkan dalam proses pengumpulan data, peneliti membuat pedoman studi dokumen. Hal ini sejalan dengan Arikunto (2006:158-159) yang menyatakan bahwa studi dokumen dapat dilakukan dengan bantuan pedoman dokumentasi yang memuat garis-garis besar atau kategori yang akan dicari datanya. Pada penelitian ini, pedoman studi dokumen berupa indikator-indikator dari masing-masing subnilai karakter.

Selanjutnya, data yang telah terkumpul dianalisis berdasarkan lima tahapan analisis data penelitian kualitatif, yaitu (1) mengumpulkan data, (2) mentranskripsikan data, (3) memahami data secara umum, (4) mengkode data, (5) membangun deskripsi untuk laporan penelitian (Creswell, 2015: 470). Untuk menjaga keabsahan data, dilakukan ketekukan pengamatan dan diskusi dengan teman sejawat untuk meninjau kembali data dan hasil penelitian yang telah ditemukan. Secara keseluruhan, penelitian ini terdiri dari 3 tahap, yaitu tahap perencanaan, pelaksanaan, dan pelaporan.

\section{HASIL DAN PEMBAHASAN}

\section{Nilai Karakter pada Tema Cerita Dongeng Modern}

Nilai karakter yang ditemukan pada tema cerita dongeng modern sebanyak 13 muatan. Nilai karakter nasionalis sebanyak 1 muatan, dengan rincian 1 subnilai karakter rela berkorban, pada judul " Kuda yang Malang". Nilai karakter mandiri sebanyak 5 muatan, dengan rincian 2 subnilai karakter keberanian dan 3 subnilai karakter menjadi pembelajar sepanjang hayat, salah satunya pada judul " Harimau Berguru kepada Kucing". Nilai karakter gotong-royong sebanyak 5 muatan, dengan rincian 1 subnilai karakter inklusif, 2 subnilai karakter tolong-menolong, 1 subnilai karakter empati, dan 1 subnilai karakter sikap kerelawanan, sperti yang ada pada judul "Gajah yang Baik Hati”. Nilai karakter integritas sebanyak 2 muatan, dengan rincian 1 subnilai karakter kejujuran dan 1 subnilai karakter keteladanan, yang terdapat pada judul " Kancil dikalahkan Siput".

\section{Nilai Karakter pada Penokohan Cerita Dongeng Modern}

Nilai karakter yang ditemukan pada penokohan cerita dongeng modern sebanyak 44 muatan. Nilai karakter religius sebanyak 8 muatan, dengan rincian 1 subnilai karakter cinta damai, 2 subnilai karakter percaya diri, 1 subnilai karakter anti kekerasan, 2 subnilai karakter persahabatan, 1 subnilai karakter ketulusan, dan 1 subnilai karakter tidak memaksakan kehendak. Nilai nasionalis sebanyak 1 muatan, dengan rincian 1 subnilai karakter rela berkorban, contohnya "Gajah...., gajah..., tolong aku!" pinta harimau sambil menahan kesakitan. Mendengar teriakan harimau 
minta tolon, gajah itu langsung mengangkat pohon yang menindih harimau dengan belalainya. "Terimakasih, kawan!" ucap Harimau. "Seandainya kamu tak segera dating menolongku, mungkin aku sudah mati karena himpitan pohon itu. Sekali lagi terimakasih." Nilai karakter mandiri sebanyak 7 muatan, dengan rincian 1 subnilai karakter kerja keras, 1 subnilai karakter tangguh tahan banting, 1 subnilai karakter daya juang, 2 subnilai karakter keberanian, dan 2 subnilai karakter menjadi pembelajar sepanjang hayat. Contohnya sebagai berikut; " Macan nakal!" tiba-tiba si Ular terbangun dari tidurnya. " Beraninya kau menganggu waktu istirahatku." Secepat kilat Ular besar itu membelit tubuh Macan dan menggigitnya disana-sini. Macan tak mau kalah ia juga balas menggigit perut ular dan mencakar- cakar tubuh Ular itu, keduanya bertarung seru dalam waktu yang lama. Nilai karakter gotongroyong sebanyak 23 muatan, dengan rincian 2 subnilai karakter kerjasama, 1 subnilai karakter inklusif, 1 subnilai karakter komitmen terhadap keputusan bersama, 3 subnilai karakter musyawarah mufakat, 8 subnilai karakter tolong menolong, 1 subnilai karakter solidaritas, 2 subnilai karakter empati, 2 subnilai karakter anti diskriminasi, dan 2 subnilai karakter kerelawanan. Contoh salah satunya adalah: Sesampainya di rumah, Siput berpikir keras untuk memikirkan cara yang paling tepat guna memberi pelajaran kepada kancil. Saat tengah malam Siput menemukan gagasan yang paling jitu. Malam itu juga ia segera menghubungi semua siput yang ada di tempat itu. Dengan sifatnya yang suka tolong menolong akhirnya semua Siput bersepakat untuk menaklukkan si Kancil dalam perlombaan lari besok pagi. Nilai karakter integritas sebanyak 5 muatan, dengan rincian 2 subnilai karakter kejujuran, 1 subnilai karakter setia, dan 2 subnilai karakter menghargai martabat individu. Contohnya adalah: Melihat sahabatnya menderita kesakitan, Kancil berusaha memberikan bantuannya. Kancil berkata, "Wah, hebat betul hari ini engkau Srigala!" Srigala kaget melihat kedatangan Kancil. "Hei cil! Apa kau juga ingin aku makan? Tunggulah sebentar, biar kumakan kuda ini dulu!" “Cil, tolonglah aku....!" Rintih Kuda. "Tenanglah kawan, aku akan menolongmu.” Kata Kancil.

\section{Nilai Karakter pada Latar Cerita Dongeng Modern}

Muatan nilai karakter yang ditemukan pada latar cerita dongeng modern sebanyak 15 muatan. Nilai karakter religius sebanyak 1 muatan, dengan rincian 1 subnilai karakter persahabatan. Nilai karakter nasionalis sebanyak 2 muatan, dengan rincian 1 subnilai karakter disiplin dan 1 subnilai karakter menjaga lingkungan. Salah satu nya karakter Kancil yang menjaga persahabatan dengan Kuda dan mau membantu Kuda saat kesusahan. Nilai karakter mandiri sebanyak 4 muatan, dengan rincian 1 subnilai karakter tangguh tahan banting, 1 subnilai karakter daya juang, 1 subnilai karakter kreatif, dan 1 subnilai karakter keberanian. Contohnya Kancil yang dengan berani melawan Buaya berkali-kali agar bisa selamat sampai di tepian danau. Nilai karakter gotong-royong sebanyak 8 muatan, dengan rincian 1 subnilai karakter kerjasama, 1 subnilai karakter musyawarah mufakat, 1 subnilai karakter tolongmenolong, 4 subnilai karakter solidaritas, dan 1 subnilai karakter anti diskriminasi. Contohnya pada sekawanan Siput yang bergotong royong demi mengalahkan Kancil dalan sebuah ajang lomba lari. 


\section{Nilai Karakter pada Alur Cerita Dongeng Modern}

Muatan nilai karakter yang ditemukan pada alur cerita dongeng modern sebanyak 46 muatan. Nilai karakter religius sebanyak 11 muatan, dengan rincian 2 subnilai cinta damai, 1 subnilai karakter teguh pendirian, 2 subnilai karakter percaya diri, 2 subnilai karakter anti kekerasan, 2 subnilai karakter persahabatan, 1 subnilai karakter ketulusan, dan 1 subnilai karakter tidak memaksakan kehendak. Alur cerita yang konsisten pada tokoh kancil yang licik dan baik hati dari awal sampai akhir. Nilai karakter nasionalis sebanyak 2 muatan, dengan rincian 1 subnilai karakter rela berkorban dan 1 subnilai karakter disiplin. Contoh nya ada pada setiap judul yang menggambarkan karakter kancil yang rela berkorban demi temannya walaupun dengan cara licik. Nilai karakter mandiri sebanyak 8 muatan, dengan rincian 1 subnilai karakter kerja keras, 1 subnilai karakter tangguh tahan banting, 2 subnilai karakter daya juang, 1 subnilai karakter kreatif, 1 subnilai karakter keberanian, dan 2 subnilai karakter menjadi pembelajar sepanjang hayat. Contohnya adalah sikap Kancil yang selalu berjuang lepas dari masalah tanpa mengenal lelah di setiap cerita. Nilai karakter gotong-royong sebanyak 18 muatan, dengan rincian 1 subnilai karakter menghargai, 1 subnilai karakter kerjasama, 1 subnilai karakter komitmen terhadap keputusan bersama, 2 subnilai karakter musyawarah mufakat, 7 subnilai karakter tolong-menolong, 1 subnilai karakter solidaritas, 1 subnilai karakter empati, 2 subnilai karakter anti diskriminasi, dan 2 subnilai karakter sikap kerelawanan. Nilai karakter integritas sebanyak 7 muatan, dengan rincian 2 subnilai karakter kejujuran, 1 subnilai karakter setia, 1 subnilai karakter komitmen moral, 1 subnilai karakter tanggung jawab, 1 subnilai karakter keteladanan, dan 1 subnilai karakter menghargai martabat individu. Terdapat contoh saat Siput dengan sukarela membantu temannya untuk mengalahkan kancil.

\section{Nilai Karakter pada Amanat Cerita Dongeng Modern}

Muatan nilai karakter yang ditemukan pada amanat cerita dongeng modern sebanyak 11 muatan. Nilai karakter religius sebanyak 1 muatan, dengan rincian 1 subnilai karakter persahabatan. Nilai karakter mandiri sebanyak 3 muatan, dengan rincian 3 subnilai karakter menjadi pembelajar sepanjang hayat. Banyak hal mengajarkan kita untuk selalu berbuat baik kepada teman karena suatu saat kita akan membutuhkan bantuan dari teman yang lain. Nilai karakter gotong-royong sebanyak 7 muatan, dengan rincian 1 subnilai karakter kerjasama, 2 subnilai karakter inklusif, 3 subnilai karakter tolong-menolong, dan 1 subnilai karakter solidaritas. Dapat kita ambil kesimpulan bahwa kerjasam dan tolong menolong akan meningkatkan rasa persaudaraan bagi hewan- hewan di hutan dan juga dapat menyelesaikan masalah dengan mudah karena adanya kerjasama.

\section{Nilai Karakter pada Sudut Pandang Cerita Dongeng Modern}

Nilai karakter yang ditemukan pada sudut pandang cerita dongeng modern sebanyak 23 muatan. Nilai karakter religius sebanyak 4 muatan, dengan rincian 1 subnilai karakter cinta damai, 1 subnilai karakter percaya diri, 1 subnilai karakter persahabatan, dan 1 subnilai karakter tidak memaksakan kehendak. Nilai karakter nasionalis sebanyak 1 muatan, dengan rincian 1 subnilai karakter disiplin. Nilai 
karakter mandiri sebanyak 5 muatan, dengan rincian 1 subnilai karakter tangguh tahan banting, 1 subnilai karakter daya juang, dan 3 subnilai karakter menjadi pembelajar sepanjang hayat. Nilai karakter gotong-royong sebanyak 9 muatan, dengan rincian 2 subnilai karakter kerjasama, 1 subnilai karakter inklusif, 1 subnilai karakter komitmen dengan keputusan bersama, 2 subnilai karakter musyawarah mufakat, 1 subnilai karakter tolong-menolong, 1 subnilai karakter solidaritas, dan 1 subnilai karakter anti diskriminasi. Nilai karakter integritas sebanyak 4 muatan, dengan rincian 2 subnilai karakter setia, 1 subnilai karakter tanggung jawab, dan 1 subnilai karakter keteladanan. Inti dari cerita tersebut bahwa berbuat baik itu sangat perlu, dan jangan mudah percaya terhadap orang lain dengan mudah. Selain itu juga mengajarkan kita untuk selalu bekerja keras dan tolong menolong terhadap sesama juga selalu bertanggung jawab terhadap apa yang sudah dilakukan.

\section{PEMBAHASAN}

Berkenaan dengan manfaat sastra anak sebagai sarana menanamkan dan mengembangkan nilai-nilai positif, Rahim (2011:89) juga telah menjelaskan bahwa sastra anak biasanya mengembangkan pemahaman afektif tentang kehidupan anakanak sehari-hari, baik dari sisi karakter maupun kondisi kejiwaannya. Peneliti terdahulu telah mengungkapkan hasil penelitiannya mengenai nilai karakter pada sastra anak. Wiwin Indiarti (2017) mengungkapkan bahwa terdapat 10 nilai karakter sebagai pembentuk karakter dalam Cerita Rakyat Asal-usul Watu Dodol, meliputi nilai religius, jujur, kerja keras, ingin tahu, semangat kebangsaan, cinta tanah air, menghargai prestasi, bersahabat/ komunikatif, peduli sosial, dan tanggung jawab. Dyah Ayu Caturningtyas pada tahun 2017 memperoleh hasil bahwa terdapat 18 nilai karakter yang dijabarkan dengan rincian, 14 nilai karakter muncul dalam unsur intrinsik tokoh, 6 nilai karakter tersebar ke dalam unsur intrinsik alur, 4 nilai karakter termuat dalam unsur latar, dan 5 nilai karakter termuat dalam unsur intrinsik amanat.

Berikut ini merupakan nilai-nilai karakter yang termuat pada sastra anak berjenis dongeng modern.

\section{Nilai Karakter pada Tema Cerita Dongeng Modern}

Muatan nilai nasionalis yang ditemukan belum sesuai dengan deskripsi dari nilai karakter nasionalis menurut Kemdikbud (2017) yang berarti cara berpikir dan bertindak yang menunjukkan penghargaan dan kepedulian yang tinggi terhadap kepentingan bangsa dan negara daripada kepentingan pribadinya mencakup bahasa, lingkungan fisik, sosial, budaya, ekonomi, dan politik. Hal ini dikarenakan muatan tersebut belum memperlihatkan adanya penghargaan atau kepedulian terhadap kepentingan bangsa dan Negara. Muatan tersebut memuat subnilai karakter rela berkorban yang berkaitan dengan kepentingan dirinya dan lingkungannya sendiri.

Nilai karakter gotong-royong termuat pada muatan ke-7, 8, 9, 10, dan 11. Muatan-muatan ini telah sesuai dengan deskripsi nilai karakter gotong-royong, yaitu tindakan menghargai semangat kerjasama dan bahu-membahu menyelesaikan persoalan bersama, menjalin komunikasi dan persahabatan, dan memberi bantuan pada orang lain yang membutuhkan (Kemdikbud, 2017). 
Nilai karakter integritas termuat pada muatan ke-12 dan 13. Kedua muatan ini telah sesuai dengan deskripsi nilai karakter integritas, yaitu nilai yang mendasari perilaku seseorang dalam mengupayakan dirinya menjadi seseorang yang dapat dipercaya dalam berbagai hal dan berkomitmen pada nilai kemanusiaan serta nilainilai yang berlaku di lingkungannya (Kemdikbud, 2017).

\section{Nilai Karakter Pada Penokohan Cerita Dongeng Modern}

Nilai karakter religius berkaitan dengan ketaatan manusia dengan Tuhannya. Religius merupakan sikap dan perilaku yang patuh pada ajaran agama yang dianutnya, toleran terhadap pelaksanaan agama lain, dan hidup rukun dengan pemeluk agama lain (Zakiyah \& Rusdiana, 2014:112). Nilai karakter religius termuat pada muatan ke-1, 2, 3, 4, 5, 6, 7, 8, dan 9. Namun, muatan-muatan tersebut belum menunjukkan tiga cakupan nilai religius, yaitu berkaitan dengan hubungan individu dengan Tuhan, individu dengan sesama, dan individu dengan lingkungan (Kemdikbud, 2017). Nilai religius pada muatan-muatan tersebut hanya mencakup halhal yang berkaitan dengan hubungan individu dengan sesama dan lingkungan. Untuk hal-hal yang berkaitan dengan hubungan individu dengan Tuhan belum termuat dalam penokohan cerita dongeng modern.

Muatan nilai nasionalis yang ditemukan belum sesuai dengan deskripsi dari nilai karakter nasionalis menurut Kemdikbud (2017) yang berarti cara berpikir dan bertindak yang menunjukkan penghargaan dan kepedulian yang tinggi terhadap kepentingan bangsa dan negara daripada kepentingan pribadinya mencakup bahasa, lingkungan fisik, sosial, budaya, ekonomi, dan politik. Hal ini dikarenakan muatan tersebut belum memperlihatkan adanya penghargaan atau kepedulian terhadap kepentingan bangsa dan Negara. Muatan tersebut memuat subnilai karakter rela berkorban yang berkaitan dengan kepentingan dirinya dan lingkungannya sendiri.

Nilai karakter selanjutnya yang ditemukan pada penokohan cerita dongeng modern yaitu nilai karakter mandiri. Suyanto (2013: 17) memaparkan definisi nilai karakter mandiri sebagai sikap yang dimiliki seseorang untuk mampu mengambil keputusan, mengarahkan dan mengembangkan diri, serta menyesuaikan diri dengan lingkungan dan aturan yang berlaku. Nilai karakter yang sesuai dengan deskripsi tersebut termuat pada muatan ke-10, 11, 12, 13, 14, 15, dan 16. Muatan-muatan tersebut juga telah menunjukkan kesesuaian bahwa individu yang mandiri mempergunakan waktu, tenaga, dan pikiran untuk mewujudkan cita-cita dan harapannya tanpa bergantung dengan orang lain (Kemdikbud, 2017).

Nilai karakter gotong-royong termuat pada muatan ke-17 sampai muatan ke39. Muatan-muatan tersebut telah sesuai dengan deskripsi nilai karakter gotongroyong, yaitu tindakan menghargai semangat kerjasama dan bahu-membahu menyelesaikan persoalan bersama, menjalin komunikasi dan persahabatan, dan memberi bantuan pada orang lain yang membutuhkan (Kemdikbud, 2017).

Nilai karakter integritas termuat pada muatan ke-40, 41, 42, 43, dan 44. Kelima muatan tersebut telah sesuai dengan deskripsi nilai karakter integritas, yaitu nilai yang mendasari perilaku seseorang dalam mengupayakan dirinya menjadi seseorang yang dapat dipercaya dalam berbagai hal dan berkomitmen pada nilai kemanusiaan serta nilai-nilai yang berlaku di lingkungannya (Kemdikbud, 2017). 


\section{Nilai Karakter Pada Latar Cerita Dongeng Modern}

Nilai karakter religius berkaitan dengan ketaatan manusia dengan Tuhannya. Nilai karakter religius termuat pada muatan ke-1. Namun, muatan ini belum menunjukkan tiga cakupan nilai religius, yaitu berkaitan dengan hubungan individu dengan Tuhan, individu dengan sesama, dan individu dengan lingkungan (Kemdikbud, 2017). Nilai religius pada muatan ini hanya mencakup hal yang berkaitan dengan hubungan individu dengan sesama dan lingkungan. Untuk hal-hal yang berkaitan dengan hubungan individu dengan Tuhan belum termuat dalam latar cerita dongeng modern.

Muatan nilai nasionalis yang ditemukan belum sesuai dengan deskripsi dari nilai karakter nasionalis menurut Kemdikbud (2017) yang berarti cara berpikir dan bertindak yang menunjukkan penghargaan dan kepedulian yang tinggi terhadap kepentingan bangsa dan negara daripada kepentingan pribadinya mencakup bahasa, lingkungan fisik, sosial, budaya, ekonomi, dan politik. Hal ini dikarenakan muatan tersebut belum memperlihatkan adanya penghargaan atau kepedulian terhadap kepentingan bangsa dan Negara. Muatan tersebut memuat subnilai karakter menjaga lingkungan dan disiplin yang berkaitan dengan kepentingan dirinya dan lingkungannya sendiri.

Nilai karakter mandiri termuat pada muatan ke-4, 5, 6, dan 7. Muatan-muatan tersebut telah sesuai dengan deskripsi nilai karakter mandiri menurut Suyanto (2013: 17), yaitu sikap yang dimiliki seseorang untuk mampu mengambil keputusan, mengarahkan dan mengembangkan diri, serta menyesuaikan diri dengan lingkungan dan aturan yang berlaku.

Nilai karakter gotong-royong termuat pada muatan ke-8 sampai dengan 15. Secara umum, muatan-muatan tersebut telah sesuai dengan deskripsi nilai karakter gotong-royong, yaitu tindakan menghargai semangat kerjasama dan bahu-membahu menyelesaikan persoalan bersama, menjalin komunikasi dan persahabatan, dan memberi bantuan pada orang lain yang membutuhkan (Kemdikbud, 2017).

\section{Nilai Karakter Pada Alur Cerita Dongeng Modern}

Nilai karakter religius berkaitan dengan ketaatan manusia dengan Tuhannya. Religius merupakan sikap dan perilaku yang patuh pada ajaran agama yang dianutnya, toleran terhadap pelaksanaan agama lain, dan hidup rukun dengan pemeluk agama lain (Zakiyah \& Rusdiana, 2014:112). Nilai karakter religius termuat pada muatan ke-1 sampai dengan 1. Namun, muatan-muatan nilai religius tersebut belum menunjukkan tiga cakupan nilai religius, yaitu berkaitan dengan hubungan individu dengan Tuhan, individu dengan sesama, dan individu dengan lingkungan (Kemdikbud, 2017). Nilai religius pada muatan ini hanya mencakup hal yang berkaitan dengan hubungan individu dengan sesama dan lingkungannya. Untuk halhal yang berkaitan dengan hubungan individu dengan Tuhan belum termuat dalam alur cerita dongeng modern.

Muatan nilai nasionalis yang ditemukan belum sesuai dengan deskripsi dari nilai karakter nasionalis menurut Kemdikbud (2017) yang berarti cara berpikir dan bertindak yang menunjukkan penghargaan dan kepedulian yang tinggi terhadap 
kepentingan bangsa dan negara daripada kepentingan pribadinya mencakup bahasa, lingkungan fisik, sosial, budaya, ekonomi, dan politik. Hal ini dikarenakan muatan tersebut belum memperlihatkan adanya penghargaan atau kepedulian terhadap kepentingan bangsa dan Negara. Muatan tersebut memuat subnilai karakter rela berkorban dan disiplin yang berkaitan dengan kepentingan dirinya dan lingkungannya sendiri.

Definisi nilai karakter mandiri menurut Suyanto (2013: 17) merupakan sikap yang dimiliki seseorang untuk mampu mengambil keputusan, mengarahkan dan mengembangkan diri, serta menyesuaikan diri dengan lingkungan dan aturan yang berlaku. sebagai sikap yang dimiliki seseorang untuk mampu mengambil keputusan, mengarahkan dan mengembangkan diri, serta menyesuaikan diri dengan lingkungan dan aturan yang berlaku. Muatan nilai karakter pada alur cerita dongeng modern yang sesuai dengan deskripsi tersebut yakni muatan ke-14 sampai dengan 21. Muatanmuatan ini telah sesuai dengan deskripsi bahwa individu yang mandiri mempergunakan waktu, tenaga, dan pikiran untuk mewujudkan cita-cita dan harapannya tanpa bergantung dengan orang lain (Kemdikbud, 2017).

Nilai karakter gotong-royong termuat pada muatan ke-22 sampai muatan ke39. Muatan-muatan ini telah sesuai dengan deskripsi nilai karakter gotong-royong, yaitu tindakan menghargai semangat kerjasama dan bahu-membahu menyelesaikan persoalan bersama, menjalin komunikasi dan persahabatan, dan memberi bantuan pada orang lain yang membutuhkan (Kemdikbud, 2017).

Nilai karakter integritas termuat pada muatan ke-40 sampai dengan 46. Keenam muatan tersebut telah sesuai dengan deskripsi nilai karakter integritas, yaitu nilai yang mendasari perilaku seseorang dalam mengupayakan dirinya menjadi seseorang yang dapat dipercaya dalam berbagai hal dan berkomitmen pada nilai kemanusiaan serta nilai-nilai yang berlaku di lingkungannya (Kemdikbud, 2017).

\section{Nilai Karakter pada Amanat Cerita Dongeng Modern}

Nilai karakter religius berkaitan dengan ketaatan manusia dengan Tuhannya. Religius merupakan sikap dan perilaku yang patuh pada ajaran agama yang dianutnya, toleran terhadap pelaksanaan agama lain, dan hidup rukun dengan pemeluk agama lain (Zakiyah \& Rusdiana, 2014:112). Nilai karakter religius yang sesuai dengan deskripsi tersebut termuat pada muatan ke-1. Namun, nilai religius dalam muatan ini belum menunjukkan tiga cakupan nilai religius, yaitu berkaitan dengan hubungan individu dengan Tuhan, individu dengan sesama, dan individu dengan lingkungan (Kemdikbud, 2017). Nilai religius pada muatan ini hanya mencakup hal yang berkaitan dengan hubungan individu dengan sesama dan lingkungannya. Untuk hal-hal yang berkaitan dengan hubungan individu dengan Tuhan belum termuat dalam amanat cerita dongeng modern.

Nilai karakter mandiri termuat pada muatan ke-2,3, dan 4. Muatan-muatan tersebut telah sesuai dengan deskripsi nilai karakter mandiri, yaitu sikap yang dimiliki seseorang untuk mampu mengambil keputusan, mengarahkan dan mengembangkan diri, serta menyesuaikan diri dengan lingkungan dan aturan yang berlaku. sebagai sikap yang dimiliki seseorang untuk mampu mengambil keputusan, mengarahkan dan 
mengembangkan diri, serta menyesuaikan diri dengan lingkungan dan aturan yang berlaku (Suyanto, 2013:17).

Nilai karakter gotong-royong termuat pada muatan ke-5 sampai dengan 11. Secara umum, muatan ke-5 sampai dengan 11 tersebut telah sesuai dengan deskripsi nilai karakter gotong-royong, yaitu tindakan menghargai semangat kerjasama dan bahu-membahu menyelesaikan persoalan bersama, menjalin komunikasi dan persahabatan, dan memberi bantuan pada orang lain yang membutuhkan (Kemdikbud, 2017).

\section{Nilai Karakter Pada Sudut Pandang Cerita Dongeng Modern}

Nilai karakter religius berkaitan dengan ketaatan manusia dengan Tuhannya. Religius merupakan sikap dan perilaku yang patuh pada ajaran agama yang dianutnya, toleran terhadap pelaksanaan agama lain, dan hidup rukun dengan pemeluk agama lain (Zakiyah, 2014:112). Nilai karakter religius termuat pada muatan ke-1. Namun muatan ini belum menunjukkan tiga cakupan nilai religius, yaitu berkaitan dengan hubungan individu dengan Tuhan, individu dengan sesama, dan individu dengan lingkungan (Kemdikbud, 2017). Nilai religius pada muatan ini hanya mencakup hal yang berkaitan dengan hubungan individu dengan sesama dan lingkungannya. Untuk hal-hal yang berkaitan dengan hubungan individu dengan Tuhan belum termuat dalam amanat cerita dongeng modern.

Muatan nilai nasionalis yang ditemukan belum sesuai dengan deskripsi dari nilai karakter nasionalis menurut Kemdikbud (2017) yang berarti cara berpikir dan bertindak yang menunjukkan penghargaan dan kepedulian yang tinggi terhadap kepentingan bangsa dan negara daripada kepentingan pribadinya mencakup bahasa, lingkungan fisik, sosial, budaya, ekonomi, dan politik. Hal ini dikarenakan muatan tersebut belum memperlihatkan adanya penghargaan atau kepedulian terhadap kepentingan bangsa dan Negara. Muatan tersebut memuat subnilai karakter disiplin yang berkaitan dengan kepentingan dirinya dan lingkungannya sendiri.

Definisi nilai karakter mandiri menurut Suyanto (2013: 17) merupakan sikap yang dimiliki seseorang untuk mampu mengambil keputusan, mengarahkan dan mengembangkan diri, serta menyesuaikan diri dengan lingkungan dan aturan yang berlaku. sebagai sikap yang dimiliki seseorang untuk mampu mengambil keputusan, mengarahkan dan mengembangkan diri, serta menyesuaikan diri dengan lingkungan dan aturan yang berlaku. Muatan nilai karakter pada sudut pandang cerita dongeng modern yang sesuai dengan deskripsi tersebut yakni muatan ke-6, 7, 8, 9, dan 10 . Muatan tersebut juga telah sesuai dengan deskripsi bahwa individu yang mandiri mempergunakan waktu, tenaga, dan pikiran untuk mewujudkan cita-cita dan harapannya tanpa bergantung dengan orang lain (Kemdikbud, 2017).

Nilai karakter gotong-royong termuat pada muatan ke-11 sampai dengan 19. Secara umum, muatan-muatan tersebut telah sesuai dengan deskripsi nilai karakter gotong-royong, yaitu tindakan menghargai semangat kerjasama dan bahu-membahu menyelesaikan persoalan bersama, menjalin komunikasi dan persahabatan, dan memberi bantuan pada orang lain yang membutuhkan (Kemdikbud, 2017).

Nilai karakter integritas termuat pada muatan ke-20 sampai dengan 23. Muatan-muatan ini telah sesuai dengan deskripsi nilai karakter integritas, yaitu nilai 
yang mendasari perilaku seseorang dalam mengupayakan dirinya menjadi seseorang yang dapat dipercaya dalam berbagai hal dan berkomitmen pada nilai kemanusiaan serta nilai-nilai yang berlaku di lingkungannya (Kemdikbud, 2017).

\section{KESIMPULAN}

Hasil penelitian menunjukkan bahwa dari 5 nilai utama yang terdapat pada kemdikbud 2017, nilai karakter yang terkandung dalam tema cerita dongeng modern, meliputi nilai mandiri, gotong-royong, dan integritas, serta terdapat muatan subnilai nasionalis (rela berkorban). Nilai karakter yang terkandung dalam penokohan cerita dongeng modern, meliputi nilai religius, mandiri, gotong-royong, dan integritas, serta muatan subnilai nasionalis (rela berkorban). Nilai karakter yang terkandung dalam latar cerita dongeng modern, meliputi nilai religius, mandiri, dan gotong-royong, serta terdapat muatan subnilai nasionalis (menjaga lingkungan dan disiplin). Nilai karakter yang terkandung dalam alur cerita dongeng modern, meliputi nilai religius, mandiri, gotong-royong, dan integritas, serta terdapat muatan subnilai nasionalis (rela berkorban dan disiplin). Nilai karakter yang terkandung dalam amanat cerita dongeng modern, meliputi nilai religius, mandiri, dan gotong-royong. Nilai karakter yang terkandung dalam sudut pandang cerita dongeng modern, meliputi nilai religius, mandiri, gotong-royong, dan 4 nilai integritas, serta 1 muatan subnilai nasionalis (disiplin).

\section{DAFTAR PUSTAKA}

\section{Pustaka Primer:}

Arikunto, S. 2006. Prosedur Penelitian : Suatu Pendekatan Praktik. Jakarta: PT Asdi Mahasatya.

Caturningtyas, DA. 2017. Analisis Nilai-nilai Karakter yang Terkandung dalam Buku Cerita Anak Berjenis Fabel. Skripsi tidak diterbitkan. Malang: FIP UM.

Creswell, J. 2015. Riset Pendidikan: Perencanaan, Pelaksanaan, Evaluasi Riset Kualitatif dan Kuantitatif. Terjemahan Helly Prajitno Soetjipto. Yogyakarta: Pustaka Pelajar.

Hendri. 2013. Pendidikan Karakter Berbasis Dongeng. Bandung: PT Remaja Rosdakarya Offset..

Iswahyuningtyas, F. 2012. Nilai-Nilai Pendidikan Karakter Pada Materi Ajar Bahasa Indonesia Kelas 2 Sd Terbitan Tiga Serangkai. Surakarta: FKIP UMS.

Kementerian Pendidikan dan Kebudayaan. 2017. Konsep dan Pedoman PPK. Jakarta: Pusat Analisis dan Sinkronisasi Kebijakan.

Permendikbud Nomor 20 Tahun 2018 tentang Penguatan Pendidikan Karakter pada Satuan Pendidikan Formal.

Rahim, F. 2011. Pengajaran Membaca di Sekolah Dasar. Jakarta: PT Bumi Aksara. 
Suyanto. 2013. Menjadi Guru Profesional. Jakarta: Erlangga Group.

Undang-undang Nomor 20 Tahun 2003 tentang Sistem Pendidikan Nasional.

Zakiyah, YQ \& Rusdiana, HA. 2014. Pendidikan Nilai : Kajian Teori dan Praktik di Sekolah. Bandung: Pustaka Setia.

Zulela. (Arikunto, 2006; Caturningtyas, 2017; Creswell, 2015; Hendri, 2013; Indiarti, 2017; Kebudayaan, 2017; Rahim, 2011; Suyanto, 2013; Zulela, 2013)2013. Pembelajaran Bahasa Indonesia: Apresiasi Sastra di Sekolah Dasar. Bandung:PT Remaja Rosdakarya

\section{Sumber Internet:}

Indiarti, W. 2017. Nilai-nilai Pembentuk Karakter dalam Cerita Rakyat Asal-usul Watu Dodol.Jurnal Kajian Sastra, 6(1), 26 41. Dari http://ojs.badanbahasa.kemdikbud.go.id/jurnal/index.php/jentera/article/view 1334 